\title{
Creating And Maintaining Instructor/Student Connection Between Class Meetings: The Use Of Eyejot-A Video Messaging Technology
}

Richard E. Lillie, Ed. D, California State University San Bernardino, USA

Xiang Liu, Ph.D, California State University San Bernardino, USA

Gerui Kang, Ph.D, University of Minnesota Duluth, USA

\begin{abstract}
Eyejot, a free video email service, makes it possible to create, send, and receive video messages over the Internet. By adding the warmth of face-to-face interaction to the traditional email message, Eyejot creates a more interactive form of communication that engages today's techsavvy students. This paper shares our experience using Eyejot to strengthen rapport and engagement between instructor and student outside the traditional classroom setting. We describe how Eyejot works and offer tips for incorporating Eyejot into course design. Student feedback offers anecdotal evidence indicating a high level of satisfaction that Eyejot brings to the teachinglearning experience.
\end{abstract}

Keywords: Eyejot, Millennial, Video Messaging, Web 2.0, Student Engagement

\section{INTRODUCTION}

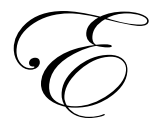

ngaging today's "Net Generation" (NetGen) business students is a challenging experience for instructors. NetGen students are technology-savvy, come to campus with an arsenal of electronic devices, and hold aggressive expectations for what should happen both inside and outside the classroom (Carlson, 2005).

NetGen students like to build social relationships. They want to connect with fellow students, instructors, and subject matter. Because their personal time is so tightly scheduled, they prefer instructors who are willing to be available before, after, and outside of the classroom (Buskist \& Saville, 2001). Their ideal instructor is someone who is approachable, easy to talk to, and willing to connect with them on an informal level when the need arises (Price, 2010).

NetGen students prefer lots of instructor-student interaction during class meetings (e.g., face-to-face encounters and instant feedback) (Thurmond \& Wambach, 2004). Assuming an instructor is successful at generating this interaction, the practical challenge then becomes how to effectively maintain the benefits of interaction and contact outside the classroom.

Research suggests there is little known about the processes that facilitate and influence the occurrence of out-of-class interaction and connection. Instructors are looking for ways to use the Internet and communication technologies used by NetGen students to make this happen (Li \& Pitts, 2009).

In this paper, we propose Eyejot, a "cloud-based" video email service, as a communications medium capable of connecting instructor and students outside of the classroom setting. We argue that Eyejot is a simple, easy to use technology tool that extends benefits of face-to-face classroom interaction and connection to interim periods between class meetings. 


\section{RELEVANT LITERATURE}

A growing body of literature suggests that incorporating technology into teaching and learning processes may enhance student learning through increased instructor-student contact. Students expect instructors to incorporate technologies into their courses and be proficient using them. At a minimum, students expect instructors to be able to use email to communicate with them outside the classroom (Wilson, 2004).

The benefits of informal instructor-student contact are well established in communications literature. $\mathrm{Li}$ and Pitts (2009) argue that as instructors increasingly use Web 2.0 technologies (i.e., software applications that operate over the Internet) to connect with students, it will be important to understand how to effectively integrate them into the classroom environment.

Hassini (2006) argues that use of email leads to a richer teaching-learning experience by providing an alternative way for instructor-student communication outside the classroom setting. His findings are similar to other researchers such as Atamian and DeMovile who use email as a substitute for office hours. They report student satisfaction with the process because students feel instructors are more accessible through email (as cited in Hassini, 2006).

Mandernach and Taylor (2011) suggest that Web 2.0 applications facilitate interaction, collaboration, and ease of information sharing. Examples of Web 2.0 applications include Facebook, YouTube, Google Docs and Spreadsheets, and Eyejot.

Guenther and Miller (2011) suggest that literature focusing on effectiveness of particular educational practices has also evolved. They conclude that to promote engagement and interaction between instructor and student, the instructor must be willing to interact with students on a personal level.

McQuillen (2003) suggests that text email is an easy way to communicate; however, it lacks audio and visual cues that make face-to-face communication effective. He suggests that it may be difficult to read the proper tone into a text message or conversation. Further, because of the lack of interactive cues, a message may be seen as impersonal and lack socio-emotional content.

Eyejot provides an efficient way to communicate with others via standard email. While asynchronous, it incorporates cues (i.e., sight and sound) that make face-to-face communication effective. It uses Internet technology to share information. Mandernach and Taylor (2011) report that students indicate greater satisfaction with Eyejot video email messages than with text email messages.

\section{HOW EYEJOT WORKS}

Eyejot is a Web 2.0, video email messaging service that goes beyond text email by making it possible to record and send video messages that include audio and video communication cues (e.g., visual appearance, tone of voice, body language, and gestures) that are key to effective face-to-face communication and interaction. Eyejot works with all web browsers and computer operating systems, cell phones that include video messaging capabilities, and new tablet computers that have built-in web cameras and WiFi or 3G/4G Internet connection capabilities. Eyejot reports that a new iPad "app" will soon be available.

There is no software to download or install. Eyejot exists in "the cloud" on servers hosted by Amazon.com. Using Eyejot is easy to do (i.e., sign onto the Internet, log into Eyejot, create an account, add contact information, record and send a video email message).

Eyejot offers both "free" and "fee" service subscriptions. The free service is convenient for students. It enables recording a video message of up to five minutes in length and includes a text message option. The free version does not allow documents to be attached to a video message. However, using Eyejot's sharing features and a little creative thinking, this limitation is easily resolved. 
The "fee" service is designed for instructors. As indicated in Figure 1, Eyejot Pro and Eyejot Pro+ versions enable recording video messages of up to 15 minutes in length and include a text message option. Eyejot Pro+ allows files of any size to be attached to a video message. The file attachment option makes Eyejot Pro+ especially useful for grading papers and providing feedback to students.

All that is needed to use Eyejot is a computer, webcam, Internet connection, and an Eyejot account. Figure 1 depicts how Eyejot and the communication process works.

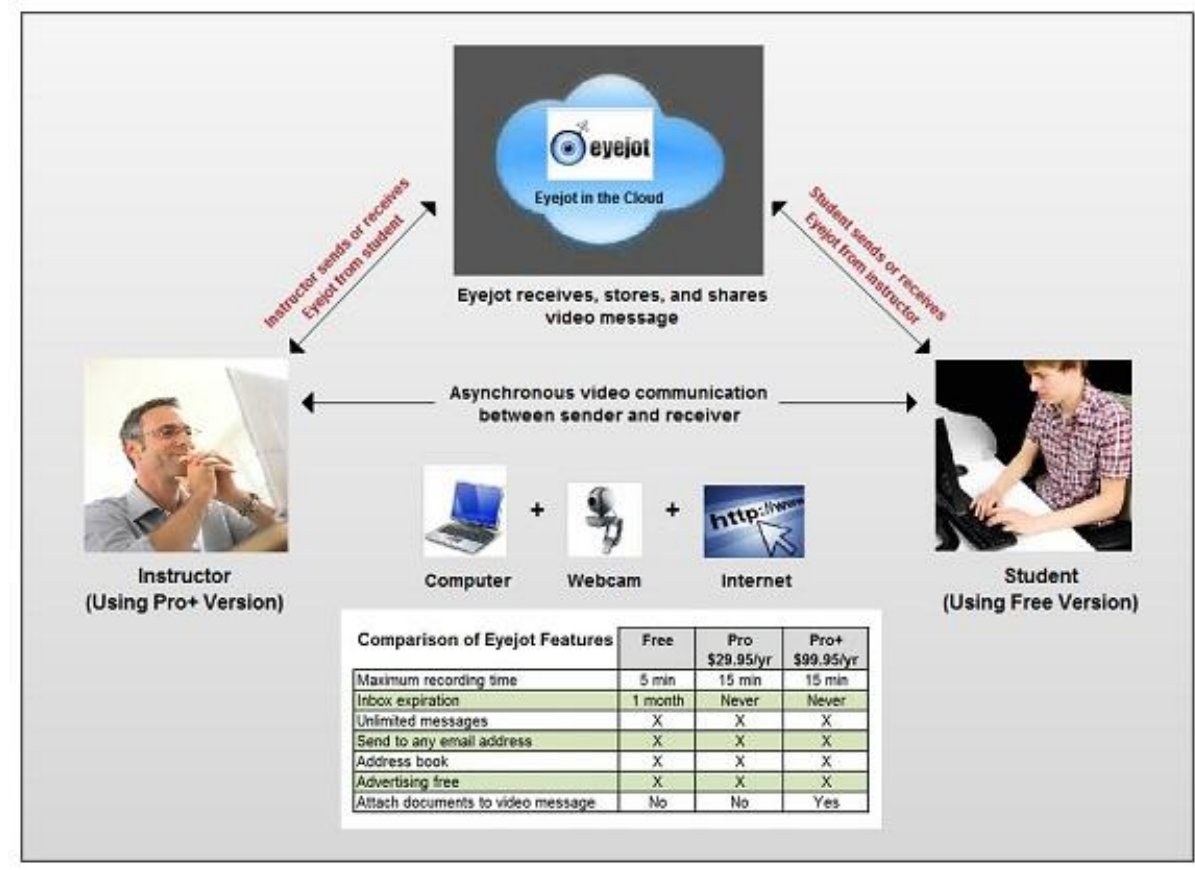

Figure 1: How Eyejot Works

\section{FEATURES AND USES OF AN EYEJOT VIDEO MESSAGE}

Eyejot creates and delivers personal, informal, conversational, video comments from one person to another. It combines features of face-to-face communication with traditional text email. The viewer can see facial expression, hand gestures, body language, and hear tone of voice. An Eyejot video message is asynchronous (i.e., a one-way, archived communication). It is not live video conferencing; rather, it is a personal video commentary delivered in an email format. Figure 2 shows the features of an Eyejot video message.

The Eyejot video message includes seven key pieces of information. Below is a brief description of each piece of information.

- $\quad$ Message title: Short message title entered when recording the video message.

- Video message: The video message is started manually by clicking a start icon (>) on the video screen. The video message may be replayed and sound volume may be controlled.

- $\quad$ Reply Option: A video message may be replied to by recording a video reply message or by typing a text message.

- Document attachment: Subscribers to the Eyejot Pro+ service may attach a file of any type or size to an Eyejot video message. This feature is particularly useful to instructors providing feedback on graded assignments.

- Date and Time of Message: Each Eyejot video message is date and time stamped in order to document the interaction. 
- $\quad$ Length of video message: The screen indicates the length of the video message. This information helps the receiver determine whether it is convenient to view a video message at the moment.

- Text Message: The text message provides a quick way to highlight key points included in the video message. Like a traditional email, an Eyejot video email message may be printed thereby enabling a recipient to keep a copy for documentation purposes.

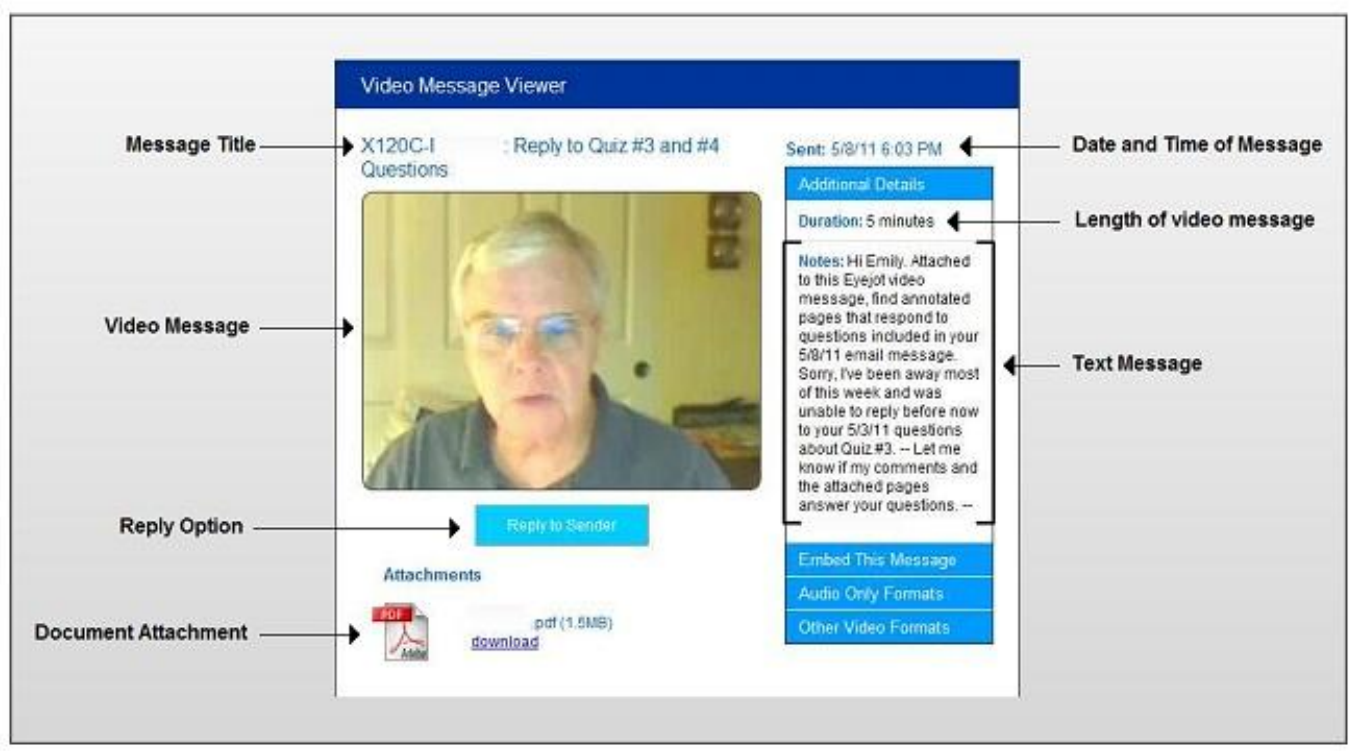

Figure 2: Eyejot Video Message Format

\section{STUDENT FEEDBACK}

We started using Eyejot to communicate with students during Fall Quarter 2010. We used it with traditional face-to-face, blended, and online Intermediate Accounting courses. Students are used to using traditional email to communicate with instructors. However, using video email messaging is something new.

Anecdotal feedback shares student reaction to using Eyejot as a way to interact and communicate throughout a course. The student population is relatively small, therefore feedback is presented qualitatively rather than quantitatively. Comments are representative of overall student feedback.

- The professor is innovative and not afraid to try new technology and keep abreast of what is going on in the profession.

- Mix of technology and real world examples made the overall course quality great and very interesting.

- In constant contact. Excellent instruction.

- I like the ability to have instant access to speak with the instructor without having to fit it into my schedule or hope that there is some mutual free time available to get my questions answered. It is much quicker than communicating through regular email and somewhat easier.

- It is very convenient. Every time I send the instructor a message response is quick. It is good to have my instructor available outside regular school office hours.

- It was really in my opinion a way of showing the instructor cared about our education and making us better students. The instructor basically provided students a way of connecting 24/7. I wish more teachers showed that much willingness to help. 


\section{CONSIDERATION OF STUDENT FEEDBACK}

Overall, students were favorable to using Eyejot as a way to communicate and interact with the instructor outside of the traditional class setting. Student feedback suggests a high level of satisfaction with Eyejot as a way to create personal, conversational connection between instructor and students.

Student feedback suggests that using Eyejot video messaging may be a way to satisfy key points addressed by researchers.

- Eyejot increases instructor-student contact outside of the classroom. Feedback suggests this enhances the teaching-learning process.

- Eyejot is a Web 2.0 application that emphasizes personal, conversational contact and sharing of information.

- $\quad$ Eyejot promotes personal contact and connection between instructor and student.

\section{ADVANTAGES OF USING EYEJOT VIDEO MESSAGING}

- $\quad$ Free version meets most student educational needs.

- $\quad$ Eyejot Pro+ version meets most instructor teaching needs.

- $\quad$ Cloud based. Requires no downloading or installation.

- Works with many computer operating systems.

- $\quad$ Works with all web browsers.

- $\quad$ Provides a reasonable message recording time.

- $\quad$ Anticipates a new iPad "app" that will make Eyejot compatible with iPad tablet.

\section{DISADVANTAGES OF USING EYEJOT VIDEO MESSAGING}

- $\quad$ Free and Eyejot Plus subscriptions do not allow file attachment to messages.

- $\quad$ Eyejot messages created and received with the free version may be saved for only one month.

- $\quad$ Requires a web camera to record a video email message.

\section{CONCLUSION}

In this paper, we propose using Eyejot video messaging, as a way to bridge and maintain instructor-student connection and interaction from one class meeting to another. Recent relative literature suggests that technology can help make this happen.

We argue that Eyejot, an asynchronous Web 2.0 communication tool that has many synchronous benefits, adds warmth to instructor-student connection between class meetings. In our experiment, students perceive this to be a favorable communication and learning experience. Based on favorable student feedback, we encourage instructors and students to use Eyejot video messaging as a way to communicate and interact outside of regular class meetings.

\section{AUTHOR INFORMATION}

Dr. Richard E. Lillie earned his EdD in Business Education and Curriculum from Northern Illinois University in 1990. He is currently an Assistant Professor of Accounting at California State University, San Bernardino. E-mail: rlillie@csusb.edu

Dr. Xiang S. Liu earned her PhD in Accounting from University of North Texas in 2009. She is currently an Assistant Professor of Accounting at California State University, San Bernardino. E-mail: xliu@ @ csusb.edu

Dr. Gerui G. Kang earned her PHD in Accounting from University of North Texas in 2008. She is currently an Assistant Professor of Accounting at University of Minnesota, Duluth. E-mail: gkang@ d.umn.edu 


\section{REFERENCES}

1. Buskist, W., \& Saville, B. K. (2001). Rapport-building: Creating positive emotional contexts for enhancing teaching and learning. APB Observer, 14(3). Retrieved from http://www.psychologicalscience.org/index.php/publications/observer/archive

2. Carlson, S. (2005). The net generation goes to college. The Chronicle of Higher Education, p. Information technology. Retrieved from http://chronicle.com/article/The-Net-Generation-Goes-to/12307

3. Guenther, C. L., \& Miller, R. L. (2011). Factors that promote engagement. In R. L. Miller, E. Amsel, Brenda Marteller Kowalewski, B. C. Beins, K. D. Keith, \& B. F. Peden (Eds.), Promoting student engagement: Volume 1: Programs, techniques, and opportunities (pp. 10-17). Retrieved from http://teachpsych.org/resources/e-books/pse2011/vol1/index.php

4. Hassini, A. (2006). Student-instructor communication: The role of email. Computers \& Education, 47, 2940.

5. Li, L., \& Pitts, J.P. (2009). Does it really matter? Using virtual office hours to enhance student-faculty interaction. Journal of Information Systems Education, 20(2), 175-185.

6. Mandernach, B. J., \& Taylor, S. S. (2011). Web 2.0 applications to foster student engagement. In R. L. Miller, E. Amsel, Brenda MarstellerKowalewski, B. C. Beins, K. D. Keith, \& B. F. Peden (Eds.), Promoting student engagement: Volume 1: Programs, techniques and opportunities. Society for the Teaching of Psychology. Retrieved from http://teachpsych.org/resources/e-books/pse2011/index.php

7. McQuillen, J. S. (2003, Spring). The influence of technology on the initiation of interpersonal relationships. Psychology and Behavioral Sciences Collection, 123(3).

8. Price, C. (2010). Why don't my students think I'm groovy?: The new "R"s for engaging millennial learners. Essays from e-xcellence in teaching, 9, 29-34. Retrieved from http://teachpsych.org/resources/e-books/eit2009/index.php

9. Thurmond, V., \& Wambach, K. (2004). Understanding interactions in distance education: A review of the literature. International Journal of Instructional Technology \& Distance Learning, 1(1). Retrieved from http://www.itdl.org/journal/Jan_04/article02.htm

10. Wilson, M. E. (2004). Teaching, learning, and millennial students. New directions for student services, 5971. doi: $10.1002 / \mathrm{ss} .125$. 